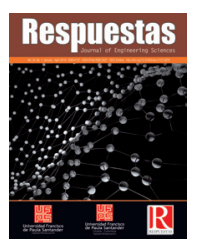

Original Article

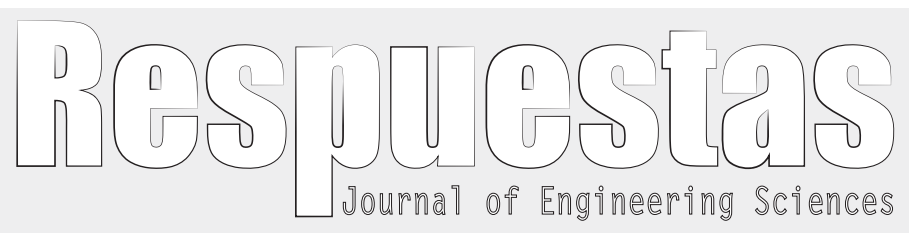

https://doi.org/10.22463/0122820X.1808

\title{
Choice of instructional design for the development of a learning environment in blended mode
}

Elección del diseño instruccional para el desarrollo de un entorno de aprendizaje en modo mixto

Doris Patricia Mora-Marín ${ }^{1 *}$, Ilber Darío Saza-Garzón², Fernando Santamaría ${ }^{3}$

${ }^{1 *}$ Magister en Educación, doris.mora@uniminuto.edu.co, ORCID: 0000-0002-1214-9158, Corporación Universitaria Minuto de Dios, Bogotá, Colombia.
${ }^{2}$ Magister en Tecnologías de la Información aplicadas a la educación, dariosaza82@gmail.com, ORCID: 0000-0002-3148-7021, Universidad Abierta y a
Distancia, Bogotá, Colombia.
${ }^{3}$ Licenciado en Filología Hispánica, fsanta@gmail.com, ORCID: 0000-0003-0381-2680, Bogotá, Colombia.

How to cite: D. Mora-Marín, I. Saza-Garzón y F. Santamaría, "Choice of instructional design for the development of a learning environment in blended mode". Respuestas, vol. 24, no. 1, pp. 64-73, 2019.

Received on May 20, 2018; Approved on October 03, 2018

\begin{tabular}{ll}
\hline ABSTRACT \\
\hline Keywords: & $\begin{array}{l}\text { This article is a part of the research process for choosing an instructional design model within an educational } \\
\text { institution of Higher Education in Colombia. It analyzes and reflects on different models of instructional } \\
\text { design and before that sustains a definition and historical evolution of the different systems that have evolved } \\
\text { Comparative }\end{array}$ \\
$\begin{array}{l}\text { Instructional design } \\
\text { Instructional }\end{array}$ & $\begin{array}{l}\text { mission and vision of the institution Minute University Corporation of God, response and choice is given to } \\
\text { a coherent model. }\end{array}$
\end{tabular}

Education

technologies

Theories

\section{RESUMEN}

Palabras clave:

Comparativo

Diseño

instruccional

Modelos de diseño

instruccional

Tecnologías

educativas

Teorías
Este artículo es parte del proceso de investigación para elegir un modelo de diseño instruccional dentro de una institución educativa de Educación Superior en Colombia. Analiza y reflexiona sobre diferentes modelos de diseño instruccional y antes de eso sostiene una definición y evolución histórica de los diferentes sistemas que han evolucionado el término de diseño instruccional. Con todos los datos y la información requerida y sobre una base coherente con la misión y la visión de la Corporación Universitaria Minuto de Dios, se da respuesta y elección a un modelo coherente.

\section{Introduction}

In this article, a study and analysis of certain key aspects of an Instructional Design (DI) are carried out that allow it to be integrated into an educational center of Higher Education, which starts from its definition and interpretation as a fundamental element that leads to optimize a virtual learning environment and that in a planning space prior to the construction of a Virtual Learning Environment / Environment (EVA in Spain and AVA in many Latin American countries, and in English VLE Virtual Learning Environment), But to create these academic spaces requires specialized software, therefore, they can be built on various platforms, among which there are free payment, [1] one that enjoys wide acceptance in

*Corresponding author

E-mail address: dpattym7@gmail.com (Doris Patricia Mora Marín)

(c) $\Theta \Theta$ Peer review is the responsibility of the Universidad Francisco de Paula Santander

cc) This is an article under the license CC BY-ND (http://creativecommons.org/licenses/by-nc-nd/4.0). 
the Hispanic academic communities is the Moodle known as a distance learning (e-learning) platform based on free software.

However, the technological elements are very important but they do not supplement all the requirements so that the educational exercise is relevant and of academic quality, consequently, it is required the integration of technological, pedagogical and didactic strategies allow to strengthen the academic processes in blended environments learning.

Through the study of various learning theories, contributions made by researchers and specialists in the field of instructional design throughout their history, as well as from the analysis of contributions and shortcomings in various theories of instructional design, the basic parameters are established that give theoretical support to the research project carried out from the Basic Information Management unit, at the Headquarters of the Corporación Universitaria Minuto de Dios, in which, from a pilot project, the creation of an instructional design is intended to support and improve the academic processes of the students of the different professional, technological and technical training programs in the face-toface modality of the Faculty of Engineering of UNIMINUTO Headquarters.

This study thus demonstrates the need to build a Virtual Learning Environment (AVA) in which the inclusion of ICTs in academic processes, was translated into new ways and methods of learning. An Instructional Design model was chosen after the analysis of the theoretical framework and models that could represent a good contribution to the proposed objectives.

On the other hand, advances in diagnostic medical imaging techniques [7], segmentation algorithms [8], [9], numerical methods for studying complex biological systems [10], [11], and capacity Growing computer equipment has marked the development of personalized medicine, once tools have been obtained to investigate the anatomical and functional complexities of patients. Diagnostic techniques.

\section{An initial approach to instructional design since its definition}

It is characteristic of the human being, of his nature, of his ability to reflect on his daily work, refer to the elaboration of a basic task or those activities that require the maximum of his mental processes, a constant critical attitude that leads him to seek strategies to improve the results obtained, looking for mechanisms, resources and different methods of execution, in order to achieve the desired quality or excellence in what he does, perhaps because of the recognition that "doing things right" is obtained, or also because it is in this way that the human being is remembered and leaves a mark, as he has expressed Eugene [2] everything happens, one thing will be told to you and it is the work well done".

Thus, this article does not address elements outside our work, on the contrary, Instructional Design is related to all those processes and resources focused on improving performance in different environments, being the educational context of special interest and importance, in which converge both the efforts of the teaching professional, educational institutions, societies and governments, which seek to offer quality education, that responds to the needs and demands of a globalized world. [3] In a joint effort to achieve efficiency and effectiveness, allowing it to reach everyone with the same quality.

And it is essentially a great effort, an unavoidable commitment that the teacher acquires, who can find in the foundations of Instructional Design the elements that he needs to achieve quality in his work. [4] Instructional Design as the analysis process carried out by the educator, who, in front of the student's learning and performance problems, designs, develops, implements, evaluates and manages resources through the use of information technologies and of ICT communications, in order to improve the academic performance of its students.

This direct relationship of Instructional Design with the term "teaching-learning", allows to broaden the definition from a more general point of view like the one given by the author [5], some define Instructional Design as an approach to self-correction systems 
that seek apply principles derived from science to the planning, design, creation, implementation and evaluation of efficient and effective instruction. However, in the educational context in which this article is intended to be focused and in particular related to the teacher and his pedagogical practices, [6] others affirm that Instructional Design as one that includes all the processes involved in optimizing learning and performance.

In an analysis presented by the research group of the Catholic University Foundation of the North [7] based on the authors Frederic Skinner, Leslie Briggs and Robert Gagné, the Instructional Design is defined based on two fundamental elements: the student's entrance behavior and the terminal objectives of the course, thus being a systematic plan that, with the arrival of technologies in the educational field, seeks for students to reach terminal objectives in a high percentage and that the teacher creates models of instructional development that allow him success in teaching processes through instructional models and the use of "teaching machines" as Skinner calls them [8] involves the experimental analysis of behavior as a branch of psychology that gives way to teaching technology, insofar as it allows us to deduce programs, plans and teaching methods that bear the fruit of being able to talk about "teaching machines and programmed instruction", elements that allow us to recognize these processes as instructional designs.

The current state of Instructional design allows this to be identified as a flexible structure in relation to the population to which it is addressed, which supports and concretes the pedagogical model that governs the institutional educational proposal [9] that will not pretend other than offering the better education, that competes and stands out against the offers of other educational institutions; innovative and attractive proposals in which elements such as the use of technologies to innovate in their methodologies, allow them to respond to the demands of a society that when transforming in great steps, requires increasingly competent professionals, a challenge that requires both institutions and To educators enrich these traditional teaching-learning processes through virtual environments in which the student finds a diversity of tools, activities, contents, which facilitate and motivate their learning according to their abilities and interests.

In that sense, from governmental entities at national and international level such as MEN and MIN TIC (Colombia) and UNESCO proposed ICT skills for teachers, as a response of integration of the technological and pedagogical, where, [10] the pedagogical practice It is a complex activity; Competent teachers apply broad, deep, and integrated sets of knowledge and skills as they plan, implement and review their pedagogical practice. The acquisition of ICT skills must be connected to the development of a wider range of teaching skills.

But it is not enough for the teacher to have mastery over the use of web tools, platforms for virtual classrooms and all kinds of emerging technologies; It is essential that you make your virtual classrooms true learning spaces, the result of your ability to analyze, identify and understand the various ways in which your students acquire knowledge and what they really should learn, [11] establishing flexible and open instructional strategies from the various learning theories that support their pedagogical work and result in planned activities and strategies designed to make the student explore, discover and exploit their abilities.

Consequently, instruction based on or supported by information and communication technologies does not adhere to a single theory, approach or methodology, since by themselves they do not respond to the multiple learning needs that the teacher meets the Inside your group, it will have different nuances that provide quality non-contact learning teaching contexts and make them part of an educational proposal available to everyone, where, for example, through behaviorism [12] the teacher generates efficient plans and strategies of reinforcement based on the student, programmed in small sequential steps that guide him in the acquisition of new knowledge through his interaction with digital materials that through repetition, response and encouragement, increase your interest in learning, thus generating a programmed learning.

Instructional designs based on cognitive contributions 
as a psychological current that result in pedagogical proposals based on theories such as Gestalt, from which fundamental elements such as significance derive, which the authors Chadwick and Vásquez speak to us [13] who affirm that Learning the most profitable is the one that radically changes people's structures, the one that impacts their vital field. This requires that what is learned makes sense to those who learn it, thus leading the teacher to generate spaces and situations that give true meaning to what the student wants to learn and convinces him of its true importance, unconventional contexts that challenge and motivate the student.

Instructional designs based on the theories of cognitive and information processing, where the teacher can find and adopt essential and key elements regarding what happens in the minds of their students when they learn, or as described by the author. [12] Learning, from this perspective, focuses on incorporating new learning into the memory structure and being able to recover and use them when needed, generating activities and strategies that take into account each of the stages from which produces knowledge, developing efficient processing strategies.

Now, if one takes into account that not all students learn in the same way and do not have the same learning style and pace [13] and [14] and that what works for some does not work for others, then it can be said that instructional designs based on the theory of cognitive skills and its interaction between aptitude and treatment, [12] lead to the construction of virtual environments that start from the student's skills understood as personal attributes that include: his intellectual ability, independence of perceptual field, anxiety, achievement of goals and location of the control, where through a diagnostic work and the use of appropriate educational materials leading the apprentice to take advantage of his own abilities or exploit those that are not properly of his facility.

The principles of evolutionary psychology of Jean Piaget in the theory of cognitive cognition, also represent a significant contribution to the field of instruction, principles that based on the stages of mental development allow the teacher to plan for his instruction a set of activities that anticipate and take into account the cognitive development of the apprentice, [11] and intend before the mere transmission of knowledge, lead the student to the development of their thought processes and allow them to assimilate it in a meaningful way.

Although the fact that an instructional design allows to achieve the expected results in the student is not only the responsibility of the teacher, in the learning process the learner has an active role, going from being a receiver to being an agent who is concerned with developing skills that allow you to learn, motivated by the expectations that new knowledge generates. Thus, through the contributions of Robert M. Gagné through his studies based on behavioral and cognitive approaches, which articulate fundamental elements of learning such as stimuli and expected learning, determined by a specific learning phase, [12] the teacher finds a significant contribution that will guide him in the generation of instructions based on strategies that promote in the student the search and development of strategies so that he learns to learn.

\section{Beginning and significant contributions in the history of instructional design}

For those who have focused their professional interest in the field of pedagogy and since their training process have led to praxis elements, theories, contributions and research of various authors such as those mentioned in the previous section, in order to improve the learning outcomes of their students, these elements are very familiar to them; however, it is very important to understand how and since when these are related to the field of instruction and how together they become today the fundamental basis in the development of learning environments that in non-face-to-face contexts contribute significantly to face-to-face education.

[6] The first steps of Instructional Design or instructional design systems (ISD) are given thanks to the work of psychologists and educators specializing in experimental research, who during the Second World War worked on the development of training materials for military training programs 
based on the principles of teaching, learning, human behavior and evaluation; results that after the war focus on solving educational problems, and that during the $40 \mathrm{~s}$ and $50 \mathrm{~s}$ of the last century begin to conceive training as something systematic to create a series of innovative analyzes in terms of design and evaluation procedures from a psychological perspective.

[6] One of the great contributions in the history of Instructional Design is made by Skinner, who revolutionizes education through his ideas regarding the requirements to increase learning and the desired characteristics of effective educational materials or programmed instructional materials, that when presenting the instruction in small steps, they should provide the student with open answers to frequent questions, immediate answers and self-stimulation through feedback. [6] For this same decade of 1900, Mager, Tyler and Gagné, make contributions no less significant that are related in their respective order with: the use of objectives for the instruction and evaluation of the same; the elaboration of criteria tests that allow to measure how well a student performs a test according to their abilities and not those of others, as well as their entry level behavior; learning conditions and instructional events. [6] The works of the authors mentioned above in the 1960s, as well as those carried out by Scriven, regarding the need to evaluate instructional materials before being applied to students, a process he called formative evaluation.

These parts of the fundamental elements that precede and serve as the basis for the evolution of instructional design in the 1970s and beyond, thus allowing the birth of instructional models in which new studies and efforts are evidenced, [15] and [16] tried to see how constructivist principles could improve the practice of instructional design. Likewise, the use of the Internet for distance learning led instructional designers to consider how online courses could be carefully designed within this new environment [17], the user-designer concept is emphasized; [18] Sahin introduced the postmodern principles of instructional design (plurality, flexibility and humanity.

[19] and [20] The concept of Instructional Design has had a development in different fields of knowledge since the sixties and seventies of the last century, but fundamentally it has been linked to the branch of psychology and from behavioral studies to learning Skinner.

\section{Instructional Design and the incursion of Technologies in Education}

[4] Technologies begin to be part of the educational processes in terms of "media", seen as the physical means that allow students to present instruction to students; Already in the first decade of the 20th century, the visual instructional movement based on the marked use of visual materials stands out; thanks to technological advances in the 1920s until the end of the 1940s, this field of instruction is extended to the audiovisual; elements that in conclusion during the first half of the 20th century highlight the use of Educational Technology as "means of instruction".

For the second half of the twentieth century in the 1960 s to 1970 s, educational technologies are seen as Instructional Technologies, from which possible solutions to teaching problems are proposed, processes that control learning processes are established, which allows Instructional Technology to be completely immersed and facilitate the teaching-learning processes. [4] It is a systematic way to design, carry out and evaluate the entire learning and teaching process in terms of specific objectives, based on research on learning and human communication, and the use of a combination of human resources and nonhuman to bring the most effective instruction.

It is important to note that in the 1970s the definition of Educational Technology was already very close in terms of the mention of processes that are later known as stages of Instructional Design, thus being Educational Technology a complex and integrated process for analyze problems and design, implement, evaluate and manage solutions to those problems; processes in which steps such as: design, production, implementation and evaluation are already mentioned for the first time.

[4] Theories of cognitive and constructivist learning, the expansion of technologies, the interest in 
distance education and teaching strategies such as collaborative work, are a great contribution that allow us to see educational technology beyond a process until mid from the 1990s, complementing this with the definitions given in 1994 where instruction is analyzed as a means to an end.

In the most recent definitions on Educational Technology, we find some particular points, the first related to ethics, defining this as a practice that should facilitate learning and improve student performance; In a second point, the role played by the student in terms of who determines what they are going to learn, the objective should be to help students apply the new skills and knowledge they have acquired.

\section{Instructional design models: introduction to instructional design models}

In this section we will describe some of the most important models of instructional design among more than one hundred models of instructional design. Each one has specifications that make it unique and each one applies to different areas: Dick $\&$ Carey is conducive to training (in certain business models and trainings) and the ADDIE model is more specific to e-learning, and learning in general.

Comparisons have been made [21] Andrews and Goodson, 1980 and frameworks [22] that help us synthesize and choose the most convenient for our institution.

\section{ADDIE model}

It is one of the most used instructional design models. It began to be used since the 60 s of the last century with different denominations, but began to be used since 1975 at the Center for Educational Technology of the University of Florida in the USA. UU. next to the 5-step approach framework developed by the US armed forces. UU and retakes the Bela Banathy model.

The ADDIE concept is being applied in this decade to build performance-based learning. The educational philosophy for this ADDIE application is that intentional learning must be student-centered, must be innovative, authentic and a source of inspiration. The concept of systematic product development has existed since the formation of social communities [23]. It is taken as a standard for design processes in e-learning and blended learning.

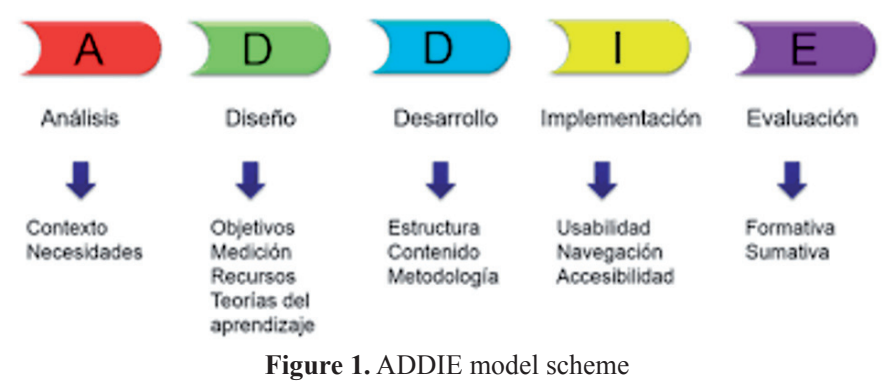

\section{Jonassen}

Jonassen's DI model is of constructivist influence. Also called Constructivist Learning Environments Model. It is based on a methodology based on the student and on the construction of one's own knowledge (learning by learning). [23] As you can see the model is based on raising questions / cases / problems / projects, disseminating cases related to the topic, so that the student builds his mental models must be given information resources, there must be cognitive tools such as some of the that Web 2.0 gives us, also collaboration tools with conversations and, finally, we must have contextual support.

It is a model that is designed for virtual learning environments and our context is not that.

\section{The instructional method of Jerrold Kemp}

This DI is very similar to that of Dick \& Carey and as this consists of many steps, specifically nine steps [25] and [26] - [27] was developed since the 70s of the last century. It is a cognitive learning design model and where the steps are interdependent, the steps do not have to follow in a particular order to complete the design of instructional learning systems. This means a systems approach in which the instructional design process is a continuous cycle, while maintaining the importance of how to manage the instructional design process. To follow the instructional process we must (1) identify the teaching problems and specify the goals for the design, (2) examine the characteristics of the students 
to have feedback for the ID, (3) analyze the tasks, (4) design the instructional objectives, (5) design the sequential content, (6) design instructional strategies, (7) plan the instructional message and its delivery, (8) develop the evaluation instruments to be able to evaluate the objectives and (9) select the resources to support the instructional activities of the learning itself.

It is not a model that serves us for lack of an order and systematic in the process as there is interdependence.

\section{ASSURE Model}

From R. Gagné and the theoretical basis of constructivism, the ASSURE model was created in 1993 (the first publication is published) by [28] the authors R. Heinrich, M. Molenda, James D. Russell and Sharon E. Smaldino (nineteen ninety-six). Each of the letters is a process instruction event:
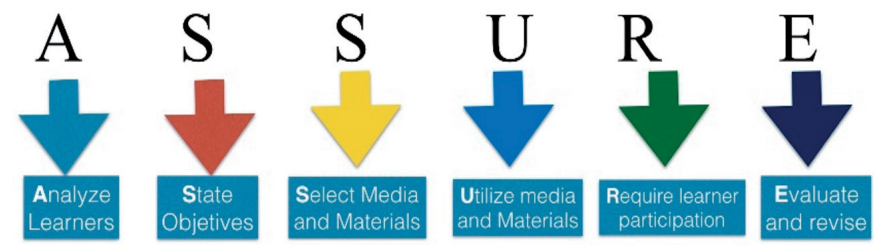

Figure 2. Scheme ASSURE model

In the first (1) the characteristics of the student are analyzed, after seeing those characteristics, (2) the learning objectives are established taking into account the previous results and (3) the materials for the didactic construction are selected, after the selection comes (4) the development and use of these teaching materials and that (5) the participation of the apprentice is required. Finally, after the participation and interaction of the students (6) there is an evaluation of results and review of the materials and of the whole process. As you can see this model takes into account the different learning styles and how you start to adjust content, you also have the active participation of this and its commitment.

The ASSURE model has been a strong rival in the final choice of a model (it also has some of this in our teacher training processes), since it is a process designed with objectives, structures and stages. Its purpose is to guide in the selection, optimal use, application and acquisition of artifacts and means to be able to make the instructional design of each subject, and that can work perfectly in blended learning environments.

\section{Dick \& Carey Model}

The Dick \& Carey model is a reductionist and behavioral perspective model. The objective of this model is to improve "directed" teaching through the practices of an instructor [29]. This model is designed through 10 components that fall into six main phases. We can see the processes in the following graphic:

The phases of the model are:

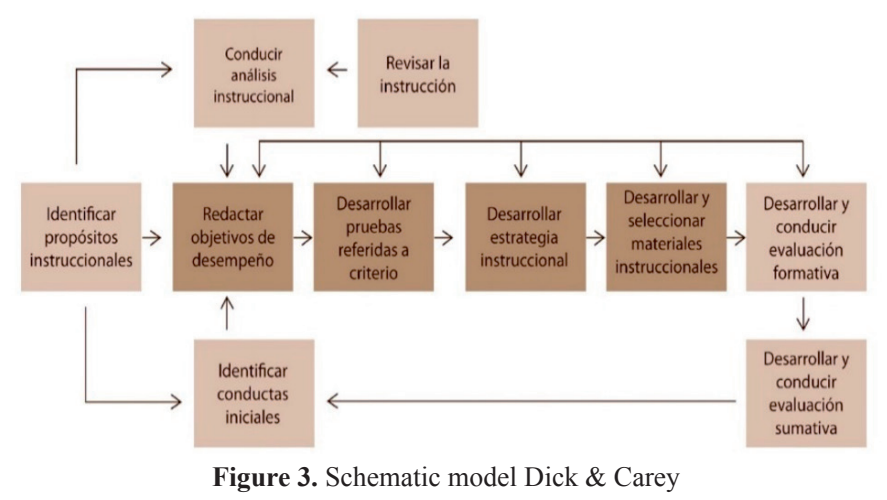

1. Identify the goal and instructional purposes.

2. Analysis of the instruction.

3. Analysis of students and context.

4. Objective writing.

5. Development of evaluation instruments.

6. Development of the instructional strategy.

7. Development and selection of instructional materials.

8. Design and development of formative evaluation.

9. Design and development of summative evaluation.

10. Review of the instruction

The Dick \& Carey model seemed complex and far from the vision and mission of the UNIMINUTO University Corporation. For teachers who are not very familiar with Instructional Design systems we find it dense in the processes and establish a metaanalysis (analysis of the same instruction).

\section{Four components (4C / ID)}

This model is based on Morin's theories from complex thinking, so this DI focuses the learning environments on the student. [30] It was designed 
by Van Merriënboer so it focuses on how to teach complex skills to solve problems in real situations.

It consists of 4 components. The FIRST deals with the tasks of learning, which must occur in a real or simulated environment and is graduating from the simplest to the most complex. SECOND is the support information, it consists of the support and represents the bridge between what you already know with the learning tasks, uses inductive and deductive strategies. THIRD is called just in time information related to the recurring aspects that indicates that the skills are applied after training (simulations) this is done by step by step how to execute certain activities. FOURTH called part-time practice includes exercise for mastery of knowledge or practical tasks, includes a series of procedures and rules and its subsequent strengthening.

As for the evaluation process, each learning task must contain the other moments and there is a greater degree of difficulty as a learning task is placed, which is why it is a constant process.

\section{Conclusions}

From the work done from the research project of the UNIMINUTO headquarters, whose main objective is to develop a proposal for Instructional Design in blended learning environments based on strategies to strengthen academic processes in the programs of the Faculty of Engineering UNIMINUTO Headquarters, the preparation of this article is established, as a space for reflection that, from the interaction with actors of the educational community, the analysis of the needs and requirements of the virtual spaces themselves and the study and documentation required for the project, as well as the results obtained lead us to conclude fundamental elements in the field of Instructional Design as:

The pedagogical context requires the teacher a constant work of prior planning that does not accommodate improvisation, since it is in this way and from appropriate activities and resources that the student will achieve the required learning objectives or results. Although this stage of planning in the face-to-face spaces helps to avoid difficulties in the teaching-learning process, in the virtual spaces this same process called instructional design means that the student has a positive perception of the process and reaches the learning results to Starting from a process where the contents, objectives and tools bring clarity to your process, with times and activities previously established, that anticipate the doubts and difficulties that the apprentice may have, with spaces and resources to maintain effective communication and relevant follow-up In this way, educational institutions and teachers provide quality virtual educational spaces to their students.

A second element to conclude in this article is based on the concern that many interested in the subject may have, and that is what is the instructional design model that I should choose; Faced with this concern, it is important to specify that Instructional Design (DI) is a process in which the contents are analyzed, designed, organized and presented with pedagogical meaning; this includes the teachinglearning strategies necessary to be applied in virtual environments; from the study of the different models made from this article it is concluded that just as the educator does not base his pedagogical processes on a single learning theory, or that the activities that serve one student to the other do not, in the field of instructional design, the model to be chosen must be adapted to the needs of the student, their context and what they want to learn, therefore, from a previous analysis work, the Instructional Design model that best suits and lead to the construction of real virtual learning spaces; therefore, the objective of this article is not to disallow or authorize the use of any of these models, it is through its exploration and analysis to establish relationships between them, identify characteristics, contributions, advantages and disadvantages that can guide the instructional designer.

In the research project in question, the ADDIE model was selected to which key elements of the praxeological approach fit as the basis of the institutional pedagogical model of UNIMINUTO, as well as specific elements of the institutional educational project, which combined with some elements of the ADDIE model serve as fundamental axis in the construction of the Virtual Learning 
Environments in blended learning modality that support the formative processes of the Faculty of Engineering of UNIMNUTO - Headquarters. ADDIE is chosen because it is a model that bases its processes on the student, combines constructivism and behaviorism as theoretical elements that guide the student in the construction of their own knowledge and through continuous evaluation processes in each of their five stages intends to avoid flaws in the process. These elements also make ADDIE a flexible and dynamic model that adapts to the different learning needs according to the context in which it is desired to apply, combines social learning and cognitivist that shape and define the result of instructional materials. Thus, in its stages and flexibility we see an opportunity to combine the elements of the UNIMINUTO praxeological approach, which allow through the pedagogical exercise to engage teachers and students in an integral formation, competent in their actions and reflective about their work.

ADDIE is a standard model from which many other models are born, which, due to its methodology through its five stages, analysis, design, development, implementation and evaluation, is related and complements the four moments of the UNIMINUTO praxeological approach to see educational needs, analyze them and execute action plans and evaluate for constant improvement.

\section{References}

[1] J. Claro-Vásquez, "Valoración del uso de la plataforma virtual Moodle como recurso pedagógico en la enseñanza universitaria de la informática", Revista Perspectivas, vol. 2, no. 1, pp. 43- 56, 2017. doi : $10.22463 / 25909215.1284$

[2] E. D'Ors, "Aprendizaje y heroísmo: Lectura dada en la Residencia de Estudiantes la noche del 20 de enero de 1915", Madrid, 1915.

[3] J, Pérez, R. López and O. M. Peralta, "Hacia una educación de calidad", 2004.

[4] R. V. Reiser and J. V. Dempsey, "Trends and Issues in Instructional Design and Technology", $3 a$ ed. Boston: Pearson, 2011.
[5] S. A. Shrock, "brief history of instructional development", En G. J. Angling (ed.), Instructional Technology: Past, Present, and Future (2. ${ }^{a}$ ed.) Englewood, IL: Libraries Unlimited Inc, pp. 11-19, 1995.

[6] R. V. Reiser, "A history of instructional design and technology, Trends and Issues in Instructional Design and Technology (3a ed.)", Englewood Cliffs, NJ: Prentice Hall College Division, 2001.

[7] G. Restrepo, "El Diseño Instruccional en la educación virtual”, El diseño, 2013.

[8] F. Skinner, "Tecnología de la Enseñanza. Barcelona. España", Editorial Labor S.A. 1982.

[9] Fundación Universitaria Católica del Norte, "En del Diseño Instruccional: Reflexiones y perspectivas en la Católica del Norte Fundación Universitaria", Medellín, Edición Coltejer, 2013.

[10] M. Martín, C. Hernández-Suarez and S. Mendoza-Lizcano, "Ambientes de aprendizaje basados en herramientas web para el desarrollo de competencias TIC en la docencia”, Revista Perspectivas, vol. 2, no. 1, pp. 97-104, 2017.

[11] S. A. Ambrose, M. W. Bridges, M. C. DiPietro, Lovett and M. K. Norman, "How Learning Works: Seven Research-Based Principles for Smart Teaching", 1th edition Jossey-Bass, 2010.

[12] A. Galvis, "Ingeniería de Software Educativo. Bogotá: Ediciones Uniandes”, 1992.

[13] C. U. Tobias, "The Way They Learn. Carol Stream, Illinois: Focus on the Family", 1994.

[14] A. Pritchard, "Ways of Learning" (2a ed.). Abingdon, Oxon; New York, NY: Routledge, 2009.

[15] W. Dick, "The Dick and Carey model: Will it survive the decade?", Educational Technology Research and Development, vol. 44, no. 3, pp. 55-63, 1996. 
[16] D. Lebow, "Constructivist values for instructional systems design: Five principles toward a new mindset", Educational Technology Research and Development, vol. 41, no. 3, pp. 4-16, 1993.

[17] M. D, Merrill, "Instructional Design Theory", Englewood Cliffs, NJ. Educational Technology Publications, 1994.

[18] A. Sharif and S. Cho, "Diseñadores instruccionales del siglo XXI: cruzando las brechas perceptuales entre la identidad, práctica, impacto y desarrollo profesional", RUSC. Universities and Knowledge Society Journal, vol. 12, no. 3, pp. 72- 86, 2015.

[19] R. C. Clark and R. E. Mayer, "e-Learning and the science of instruction: proven guidelines for consumers and designers of multimedia learning", (3a ed.). San Francisco, CA: Pfeiffer, 2011.

[20] M. Arshavskiy, "Instructional design for eLearning: essential guide to creating successful eLearning courses", S.l.: Your eLearning World, 2013.

[21] D. H. Andrews and L. A. Goodson, "A comparative analysis of models of instructional design", Journal of instructional development, vol. 3, no. 4, pp. 2-16, 1980. doi: 10.1007/ BF02904348.

[22] G. S. Edmonds, R. C. Branch and P. Mukherjee, "A conceptual framework for comparing instructional design models", Educational Technology Research and Development, vol. 42, no. 4, pp. 55-72, 1994. doi:10.1007/ BF02298055

[23] R. M. Branch, "Instructional design: the ADDIE approach”, New York: Springer, 2009.

[24] D. Jonassen, "El Diseño de entornos constructivistas de aprendizaje En: Ch. Reigeluth (Eds). Diseño de la instrucción Teorías y modelos. Un paradigma de la teoría de la instrucción", Parte I. Madrid: Aula XXI Santillana, pp. 225-249, 2000.
[25] J. E. Kemp, "Instructional design; a plan for unit and course development", Belmont, Calif.: Fearon Publishers, 1971.

[26] J. E. Kemp, "Planning, Producing, and Using Instructional Technologies", $7 a$ edition New York: Allyn \& Bacon, 1997.

[27] G. R. Morrison, S. M. Ross, J. E. Kemp and H. Kalman, "Designing effective instruction", Hoboken, NJ: J. Wiley \& Sons, 2004.

[28] R. Heinrich, M. Molenda, J. D. Russell and S. E. Smaldino, "Instructional Media and Technologies for Learning (7a ed.)", Upper Saddle River, N.J: Prentice Hall, 1996.

[29] R. D. Tennyson and S. Dijkstra, "Instructional Design: Theory, research, and models", Routledge, 1997.

[30] P. Muñoz, "Modelos de Diseño Instruccional utilizados en ambientes teleformativos", Revista Digital de Investigación Educativa Conect@2,no.2,pp.29-59, 2011. 